\title{
STATEMENT OF OWNERSHIP, MANAGEMENT AND CIRCULATION
}

(Act of August 12, 1970; Section 3685, Title 39, United States Code)

1. Publication Title: POWDER DIFFRACTION

2. Publication No.: 0885-7156

3. Filing Date: October 1, 1995

4. Issue Frequency: Quarterly

5. No. of Issues Published Annually: 4

6. Annual Subscription Price: $\$ 95.00$

7. Complete Mailing Address of Known Office of Publication: 500 Sunnyside Boulevard, Woodbury, NY 11797-2999

8. Complete Mailing Address of Headquarters or General Business Office of Publisher: One Physics Ellipse, College Park, MD 207403843

9. Full Names and Complete Mailing Addresses of Publisher, Editor, and Managing Editor:

Publisher: American Institute of Physics, One Physics Ellipse, College Park, MD 20740-3843

Editor: Deane K. Smith, Dept. of Geosciences, Penn State University, University Park, PA 16802-2711

Managing Editor: Ron Jenkins, International Center for Diffraction Data, 12 Campus Blvd., Newtown Square, PA 19073-3273

10. Owner (If owned by a corporation, its name and address must be stated and also immediately thereunder the names and addresses of stockholders owning or holding one percent or more of total amount of stock. If not owned by a corporation, the names and addresses of the individual owners must be given. If owned by a partnership or other unincorporated firm, its name and address, as well as that of each individual, must be given. If the publication is published by a nonprofit organization its name and address must be stated.) JCPDS-International Center for Diffraction Data, 12 Campus Blvd., Newtown Square, PA 19073-3273

11. Known Bondholders, Mortgagees, and Other Security Holders Owning or Holding 1 Percent or More of Total Amount of Bonds, Mortgages, or Other Securities: None

12. The purpose, function, and nonprofit status of this organization and the exempt status for federal income tax purposes: Has Not Changed During Preceding 12 Months.

13. Publication Name: Powder Diffraction

14. Issue Date for Circulation Data Below: June

15. Extent and Nature of Circulation:

a. Total No. Copies (Net Press Run)

Average No. Copies Each Issue During Preceding 12 Months

1. Sales Through Dealers and Carriers,

Street Vendors, and Counter Sales

2. Paid or Requested Mail Subscriptions

c. Total Paid and/or Requested Circulation

d. Free Distribution by Mail

e. Free Distribution Outside the Mail

f. Total Free Distribution (Sum of $d$ and e)

g. Total Distribution (Sum of $c$ and $f$ )

h. Copies Not Distributed

1. Office Use, Leftovers, Spoiled

2. Returns from News Agents

i. Total (Sum of g, h1, and h2)

Percent Paid and/or Requested Circulation $(\mathrm{c} / \mathrm{g} \times 100)$ 1,234

0

Actual No. Copies of Single Issue Published Nearest to Filing Date 1,265

\section{0}

$\begin{array}{rc}828 & 735 \\ 828 & 735 \\ 79 & 81 \\ 0 & 0 \\ 79 & 81 \\ 907 & 816 \\ 327 & \\ 0 & 449 \\ 1,234 & 0 \\ 91.29 \% & 1,265 \\ & 90.07 \%\end{array}$

16. This Statement of Ownership will be printed in the December issue of this publication.

I certify that all information furnished on this form is true and complete.

ARTHUR T. BENT Treasurer 


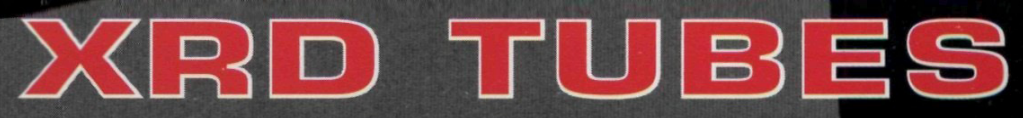

- Extra large and extra thin Be-window for a high intensity X-ray beam, specially suited for long fine

- Razor sharp focal spots ensure beam brilliance.

- Spectral purity

- Efficient cooling system for extended anode life.

- Full line of tubes 5 different focal spots, 7 different target materials, 2 different anode lengths. compatible with European style towers.

- Designed and manufactured under ISO 9001 standards. Backed by a world wide warranty of 2500 hrs.

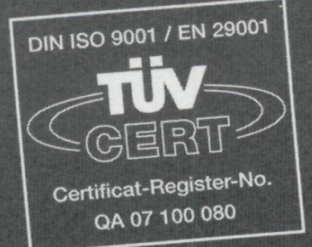

- World wide fast and friendly service, available through SEIFERT authorized service stations and re-sellers.
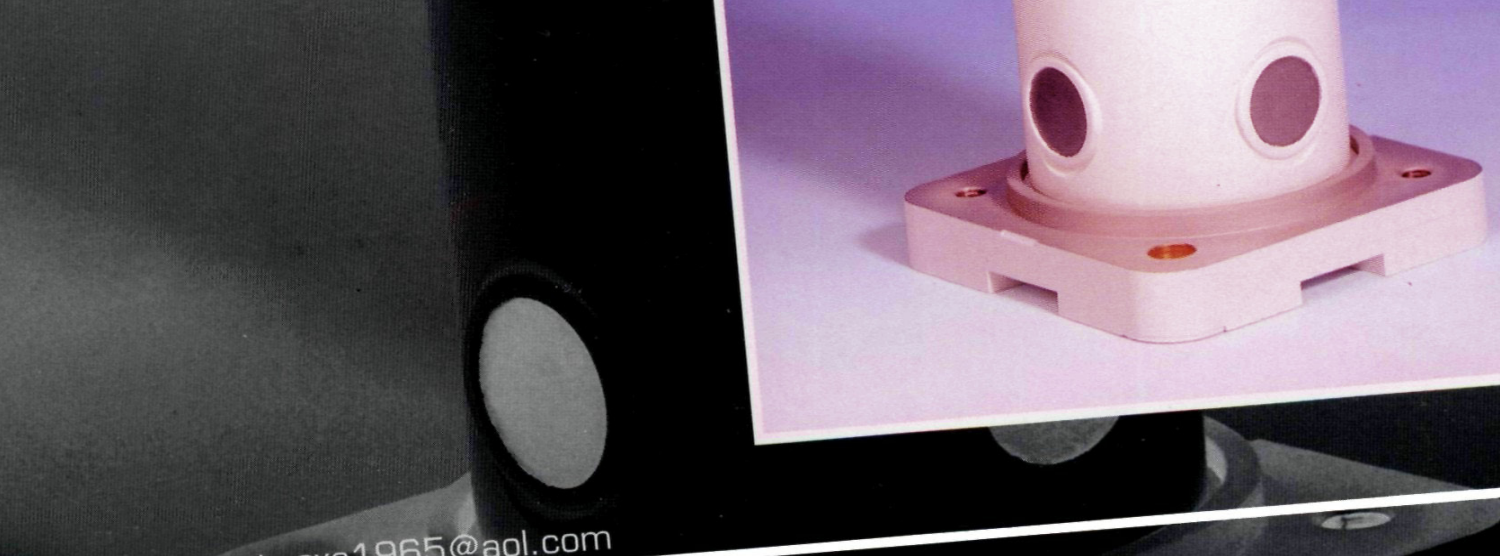
